\title{
PARODYING AND TRANSVESTING THE HISTORIC: LIZ LOCHHEAD'S MARY QUEEN OF SCOTS GOT HER HEAD CHOPPED OFF
}

\author{
CARLA RODRÍGUEZ GONZÁLEZ \\ Universidad de Oviedo
}

\begin{abstract}
When Mary Queen of Scots Got Her Head Chopped Off was premiered in the late eighties, contemporary Scottish literature adopted unprecedented perspectives, through its satiric representation of the hierarchical transmission of ideologies in the nation. The play was written for Communicando Theatre Company, as part of the 1987 tributes to Mary Stuart in the fourth centenary of her death. This paper examines the text in a moment of special relevance for contemporary Scottish history, when claims for cultural and political autonomy from English models were starting to consolidate in the nation.
\end{abstract}

Key words: contemporary Scottish literature, postmodernism, nationalism, gender and postcolonial theory.

\section{RESUMEN}

Con el estreno de Mary Queen of Scots Got Her Head Chopped Off a finales de los ochenta, la literatura escocesa adoptó nuevas perspectivas, debido a su representación satírica de las transferencias ideológicas de la nación. Escrita para Communicando Theatre Company, para homenajear el cuarto centenario de la muerte de María Estuardo (1987), la obra obtuvo un éxito inmediato y recibió el Scotsman Fringe First Award. Este artículo examina la relevancia del texto en un momento de la historia escocesa fundamental para reforzar la identidad con la que se ha reclamado recientemente la autonomía política y cultural respecto a Inglaterra.

Palabras clave: literatura escocesa contemporánea, postmodernismo, nacionalismo, teoría postcolonial y de género. 
Rewriting the historic irremediably connotes the subversion of collective narratives in the framework of contemporary criticism. In a nationalist context, where the world is conceived of as "a product of the interplay of various communities, each possessing a unique character and history, and each the result of specific origins and developments" (Smith, 1999: 175), national agendas directly depend on the efficacy of their narratives to succeed through time. Historical records -the evidence of collective memory- narrate the heroism of forefathers, their essential role in the project of nation-building which, as Benedict Anderson points out, depends far more on the effects of "amnesia" rather than on accurate remembrance, since "[identity] because it can not be 'remembered', must be narrated. (...) As with modern persons, so it is with nations." However, this apparent parallelism reveals deeper issues when concentrating on the inverse chronology of political identification, that is, when we become aware of the selective appropriation of signified genealogies; when "these violent deaths [are] remembered/forgotten as 'our own"" (1999: 205). Yet if this resignification adjusts to circumstantial needs within the legitimacy of official discourse, the transmission of collective meaning can obviously be altered by the interference of counternarratives. So is the case with Liz Lochhead's postmodern version of Mary Stuart, Mary Queen of Scots Got Her Head Chopped Off (1989), an iconoclastic representation of "the last queen of an independent Scotland."

Mary Stuart, Mary Queen of Scots, is one of the figures in Scotland's history whose image has openly been subject to the constant redefinition of cultural texts. With the passing of time, the icon has been assigned various antithetic identities born out of clear political agendas to either warn against women's wickedness or to represent the religious/ nationalist oppression of the groups that claimed revenge of her death at Protestant/English hands. Lochhead's text disrupts these narratives through the caricaturisation of a sixteenthcentury Scotland that subversively mirrors social prejudice in Thatcherite Britain. Indeed, these texts on which tradition lies provide optimal space to negotiate the monolithism of social roles in 1980s Scotland, since contemporary prejudice appears as part of a longlasting tradition responsible for internal asymmetries in the nation, where this heritage of opposition is subject to contextual redefinition. Lochhead describes her text as "a metaphor for the Scots today" (Varty, 1993: 162), and comments:

Mary, Queen of Scots, (...) is quite a difficult thing to write about without being corny or romantic. It's really about Scotland, more about the present than the past, how these myths of the past have carried on into the present malaise of Scotland today. She was around when a lot of the things that rule Scotland today were forming and hardening, you know, misogyny, Calvinism, all sorts of stuff like that (Wilson, 1990: 9).

For a start, the title, Mary Queen of Scots Got Her Head Chopped Off, a line from a nursery rhyme, warns the audience about the iconoclastic representation of the historical episodes to come and advances the parodic strategies used to subvert the absolute reliability of historical narrations. The play shows how the space liberated by parody, with the intentional distance it keeps from the imitated object, can echo -repeat and distort, but also make audible - the way collective texts are appropriated and resignified to serve different political purposes. In fact, the central -if passive- space occupied by Mary Stuart 
in the title conceals the relevance of other characters such as La Corbie and Elizabeth, her foe in History, who will contribute to knit the text of the story, highlighting how outstanding figures belong in a context created by polyphonic interventions. Linda Hutcheon's reflections on the power of parodic strategies are relevant in this sense: "I would want to argue that postmodernist parody is a value-problematizing, denaturalizing form of acknowledging the history (and through irony, the politics) of representation" (1989: 93). Although Hutcheon's analysis deals with parody in more general terms than the "notions of wit and ridicule" (93) associated with the genre since the eighteenth century, in the case of Mary Queen of Scots Got Her Head Chopped Off, humour and grotesque -carnavalesquerepresentations function as fundamental subtexts in the questioning of Scottish tradition through the polysemic myth of the sixteenth-century queen. The narration of Scotland's past is also interfered with by the fragmentary structure of the play, its anachronism and frequent Brechtian Gests, but also -and perhaps more obviously- by the constant transformation of historical characters at the commands of a most peculiar mistress of ceremony, La Corbie, in charge of revealing in her sardonic interventions the different discourses that have contributed to create a stereotyped Scotland. Her role is essential in the play, since Lochhead describes her as "the sprit of Scotland" (McCulloch, 2000: 13). La Corbie works as an unreliable chorus who, instead of representing the voice of the community or judging the action according to social standards, involves the audience in the creation of meaning as the performance proceeds, transgressing the way ideology is traditionally transmitted. Thus the discursive monologues that construct Scottish identity translate into a dialogic monologue with which La Corbie, "an interesting, ragged ambiguous creature" (11), introduces the first scene of the play, "Scotland, Whit Like?," where we are invited to collaborate with her irreverent and subjective description in Scots (11).

LA CORBIE: Country: Scotland. Whit like is it?

It's a peatbog. It's a daurk forest.

It's a cauldron o'lye. A saltpan or a coal mine.

If you're gey lucky it's a bricht bere meadow or a park o'kye.

Or mibbe ... it's a field o'stanes.

It's a tenement or a merchant's ha',

It's a hure hoose, or a humble cot. Princess Street or Paddy's

Merkit.

(...) It depends. It depends ... Ah dinnna ken whit like your Scotland

is. Here's mines.

National flower: the thistle.

National pastime: nostalgia.

National weather: smirr, haar, drizzle, snow.

National bird: the crow, the corbie, le corbeau, moi!

As the fragmentary references compose this subjective representation of Scotland, we observe how the randomly-selected icons converge in the "national bird", our narratress, who names herself in three languages -English, Scots, French-, relevant in Mary Stuart's 
life. ${ }^{1}$ Linguistic transition from one language to another plays with referentiality in such a way that her identity -Scottish national identity-directs to an emphatic "moi", the sign of an authoritarian but multiple self that will be questioned throughout the play. Robert Crawford, in his Bakhtinian approach to Lochhead's works, finds this polyphonic representation essential to negotiate difference: "[m]uch of Lochhead's writing is at its best in the border territory where self and other (as Bakhtin likes to have it) partake of each other, the zone of crossover, fluidity, shape-changing, pun" (1993: 69). In fact, Lochhead makes use of a variety of linguistic registers from the West coast of Scotland, the space where most of the "working-class men" live and work, along with several variants of standard English. ${ }^{2}$ If, as Linda Mugglestone states, "[1]anguage is, of course, of prime importance in encoding the values and assumptions of a particular culture, evidencing notions of bias and inequality, of hierarchy and social stereotypes, in the division of semantic space which results" (1993: 103), Lochhead's plural text is most efficient to reflect the interstice where social asymmetries are negotiated. Interviewed by Emily Todd, Lochhead states: "Scots is a fantastic language for multiplicity of register. There are all kinds of very, very local and particular class and almost gender and certainly geographical divisions" (1995: 125).

In Mary Queen of Scots Got Her Head Chopped Off, this subversion is inscribed within the transnational microstate -England/Scotland caricaturised- represented in the play, especially through Mary Stuart's heteroglossic speech: "(We have by now noticed MARY's strange accent - a Frenchwoman speaking Scots, not English, with, at the beginning of the play, getting subtly less as it proceeds, quite a French accent)" (13). A stranger in the community, her voice was difficult for the author to find: "I didn't know what noise Mary should make. You know the English people had to speak English and the Scots played the Scots" (Todd, 1995: 127). Mary Stuart, a multicultural sign where historical antithetic narrations converge, becomes then the sign where any totalizing discourse is subverted; the space where the différance of Scottish national identity reveals the inconsistency of a hierarchically-constructed otherness, both within Scotland and as regards its relations with other communities. Yet another important issue at stake when considering this difference is the role of collective memory. Postcolonial critic Homi Bhabha theorises on the importance of time in this respect. From his perspective (1994 [1990], 2000 [1994]), the representation of the past is essential to understand the way difference is negotiated and to see how certain "new" identities are incorporated -"authorised"- to the social norm, since the representation of the past irremediably links two times of the mind -past and future- that conceal ideological variation. Added to this, the fuzzy borders of cultures

\footnotetext{
1 Margery Palmer McCulloch connects La Corbie's role to the ballad tradition in Scotland, a field Lochhead has recurred to in other occasions. In this case, Palmer McCulloch alludes to the ballad of "The Twa Corbies" (2000: 14), an irreverent variant of "The Three Ravens," from 1611, where two crows decide how to apportion the corpse of a dead knight, instead of moaning his death, as happens in the original. As we will see later on, the last scene in Lochhead's text, "Jock Tamson's Bairns," resembles the ballad in obvious ways.

${ }^{2}$ Lochhead's perspective on gender relations in Scotland differs from traditional representations of the community, like those of the Scottish Literary Renaissance intellectuals -the nationalist movement of the early twentieth-century- who demanded a masculine working-class subject as representative of Scottish identity.
} 
that co-exist also destabilise linear chronological narrations: "[t]he borderline of culture demands an encounter with 'newness' that is not part of the continuum of past and present" (2000 [1994]: 7). These are the continuously redefined texts of interacting cultural groups, the texts of a plural nation with mobile hierarchies that intertwine in Mary Stuart's mythic and unfixed identity.

La Corbie's role is interesting in this sense, as "ambiguous, ironic" "spirit of Scotland," since she will be the tragicomic narrative and performative link between the nation's historical times. As mistress of ceremonies, she introduces the characters in an irreverent way, questioning the authority of Scotland's history: "Laughing, LA CORBIE cracks whip for THE ENTRANCE OF THE ANIMALS. In a strange circus our characters, gorgeous or pathetic, parade: MARY, ELIZABETH, HEPBURN, DANCER/RICCIO, KNOX, DARNLEY (...). They circle, snarling, smiling, posing" (12). Another resource that contributes to subvert the historic is the recurrence of anachronism throughout the play, a strategy Diane Purkiss considers fundamental to denaturalise the timeless prestige of cultural myths (1992: 446) and that Elaine Aston finds essential to underline the construction of normative "reality" (1994: 54). In this sense, Lochhead's text brings an interstice -between multiple pasts and presents- where the coherence of historical records is under constant attack and where Scottish cultural identity experiences the transformations Stuart Hall finds common to all cultural groups:

Cultural identity (...) is a matter of 'becoming' as well as of 'being' It belongs to the future as much as to the past. It is not something which already exists, transcending place, time, history and culture. Cultural identities come from somewhere, have histories. But, like everything which is historical, they undergo constant transformation. Far from being eternally fixed in some essentialised past, they are subject to the continuous 'play' of history, culture and power. Far from being grounded in mere 'recovery' of the past, which is waiting to be found, and which when found, will secure our sense of ourselves into eternity, identities are the names we give to the different ways we are positioned by, and position ourselves within, the narratives of the past (1993 [1990]: 394).

This "different positioning" of the self is revealed in the play by the constant interchangeability of the characters who, as representatives of stereotypical roles in the history of the nation, adopt opposing identities that transcend national, class and religious borders: as an example, Mary (Stuart) becomes Marian, Elizabeth's maid and adviser, but also Mairn, "a wee poor Scottish beggar lass" (32) who incarnates Knox's sexual fantasies. This denaturalising strategy is particularly relevant if we notice that commuting pairs usually invert hierarchies, as in Mary and Elizabeth's relationship, where both queens transcend contemporary representations of power between Scotland and England. La Corbie describes them at the beginning of the play:

LA CORBIE: Once upon a time there were twa queens on the wan green island, and the wan green island was split inty twa kingdoms. But no equal kingdoms, naebody in their richt mind would insist on that. For the northern kingdom was cauld and sma' And the people were low-statured and ignorant and feart o' their lords and poor! They were starvin' And their queen was beautiful and tall and fair and ... Frenchified. The other kingdom in the island was 
large, and prosperous (...) and, at the mouth of her greatest river, a great port, a glistening city that sucked all its wealth to its centre which was a palace and a court of a queen. She was a cousin, a clever cousin a wee bit aulder, and mibbe no sae braw as the other queen, but a queen nevertheless. Queen o' a country wi' an army, an' a navy and dominion over many lands (12).

Gender roles are determinant. On the one hand, England -described in terms of order and prosperity- is ruled by an intelligent woman, Elizabeth, masculinised as England is in its relation with its colonies. Mary's depiction, on the other hand, emphasises her weaknesses as a woman: a beautiful queen rules a divided kingdom as a foreigner. Contrary to traditional analysis of these women's policies, Lochhead focuses on the personal side of such gender identifications and performances, that in Mary's case lead to a symbolic death where the dissociation of mind and body is represented in a visual way, an experience Elizabeth shares much more than historical records have pointed out. In this sense, "Repressed Loves," scene five in the play, pictures one of Elizabeth's nightmares, her fear of losing her crown if she ever marries a man -Robert Leicester-, because she vividly bears in mind how her father Henry the eighth ordered her mother's decapitation.

ELIZABETH: Leicester? Dad? ... Dad? ... Mother? Robert?

(In dream lighting and strange music, very stylized, FIDDLER comes on with a doll whose head is off and she holds it separate by the hair (...)

No! No! Don't ... don't kill her. Dad? Want my Mam. Want Robert!

(Shadowy figure (Dad) puts something - not a crown but an improvised and very clear representation of one-on FIDDLER's head. Everyone cheers wierdly. Dad-figure chucks doll away.) (...)

(All the men throw FIDDLER from one to the other, kissing her. Her crown keeps nearly falling off but she holds it on. They blindfold her, spin her round, a game of blindman's-bluff. She goes to one man very slowly, deliberately, head held high. They are 'married' by the others. She turns round to kiss him, eyes shut, trusting. He steals her crown. All the 'dream people' laugh in a surreal, nightmarish, horrible way. (24)

Elizabeth's masculinisation is, hence, a strategy to escape patriarchal authority, which appears as the ultimate force behind the antagonism between the two queens: "ELIZABETH: Methinks they do try to play me and my Scotch cousin off against each other" (14). Mary expresses similar ideas: "MARY: Indeed I wish that Elizabeth was a man and I would willingly marry her! And wouldn't that make an end of all debates?" (15). In spite of the fact that this kind of representation gets close to ideas about the political possibilities of a sisterhood of women from different backgrounds that some feminist critics have defended, Lochhead's text does highlight the relevance of contextual influence to analyse how these two women's lives differed. In this respect, the way the characters -and the actressesinterchange roles is essential to understand the construction of both queens, and also a clear method to underline the performative character of identities, a strategy that Jan McDonald and Jennifer Harvie consider of great relevance to destabilise empathic alliances between the audience and one of the characters, widening the scope of identifications: “(...) the play's audiences are presented with increasingly unresolved and unresolvable texts, thus suggesting that the process of creating meaning may be more significant than 
any stable meaning" (1993: 136). Besides, the only opportunity for the two queens to meet -an episode that never happened in "real" history- will be their transformation into their rival's maid.

MARIAN: (...) Madam, you know I love you well.

ELIZABETH: Yes, Marian, like all good subjects, I hope.

MARIAN: Then, madam, I beg you marry the Earl of Leicester, for there is such a scandal, a babble getting louder and louder all the time (...).

ELIZABETH: We do love him right well, indeed.

MARIAN: And he you - madam, I do not think much heed is paid to the bad things some people say, and if you married ...

ELIZABETH: I have always said I shall marry - if I marry - as queen and not as Elizabeth. You think because my subjects love me as their queen they'll have me marry where I will?

MARIAN: Madam, I know so. Marry my lord Leicester, and live in happiness, that England shall be a peaceable kingdom.

(ELIZABETH's smile says 'perhaps'. Is she tempted? We think so ...) (18).

Scene six, "Mary Queen of Scots' Progress and John Knox's Shame," offers another level of representation. At this stage, Mary and Elizabeth become two beggars who meet John Knox in one of Mary's processions through the streets of Edinburgh, both subverting even more traditional representations of the queens and revealing the irrelevance of religious and political institutions for ordinary people. The queens' identities -that will be manipulated by the other characters along the play- are in the hands of the Reformer this time, who projects his bigotry, misogyny and repressed sexual desire on Mairn/Mary:

(MAIRN suddenly straight and tall, totally MARY in our eyes, and in KNOX's, as he chides a cheeky wee harlot on the cauld Canongate. KNOX's hand raised in anger but stayed in awe.)

KNOX: By Christ. Ah'll tan yir arse fur ye ya wee hoor o' Babylon. Lukk at ye! Wi' yir lang hair lik' a flag in the wind an advertisement o' lust tae honest men an' they big roon een lik' a dumb animal, slinkan alang the road wi' yir hurdies hingin' oot yir sark an' yon smell aff ye, ya durty wee fork-arsed bitch ye. Nae wunder it is written in the Guid Book that your kind are the very gate and port o' the devil - Ah'll leave the rid mark o' ma haun on your white flesh afore $\mathrm{Ah}-$

(Moment of ambiguity passes, it's a wee tart again, KNOX is back in control of himself.)

Awa' and behave! Pray God forgive you and sin nae mair (33).

Yet this interchangeability mixes with intertextual references in sections like "Mummers and Murderers," where the Dance of Salome is used -as it happened in Elizabethan theatre- to establish connections between the text and the parody represented in the fragment, both to reveal the instability of identities and the role of the narrative and the performative to fix the meanings attached to the self. The scene focuses on the murder of Riccio-Mary's Catholic adviser-at the hands of a Darnley -Mary's husband-instigated by the Scottish nobles whose name history has been prone to silence. La Corbie does not hesitate to enumerate their responsibility: 
LA CORBIE: There's Ruthven and Morton and Lindsay and Lethington

Ormiston, Brunstane, Haughton and Lochlinnie

There's Kerr o' Fa'donside, Scott, and Yair and Elphinstone

There's Ballantin' and Douglas

There's Ruthven and Morton ... (56)

Transformed into two anonymous beings, the Mummers -the nobles- push Mary, Darnely and Riccio to perform a "mellow-drama that entails/ Sex and lust at the court of King Herod/ - Plus the Dance of the Seven Veils" (52), that is, they redistribute the historical roles played by Mary, her adviser and her husband, in order to design a new and iconoclastic version of John the Baptist's murder. Contrary to previous versions, Lochhead's rejects female responsibility on the murder, a sin for which the whole community suffers the consequence in previous texts. In fact, gender roles are transgressed in the sequence, since Darnley incarnates Salome, representing a kind of vicious masculinity that destroys his wife's political power. Darnley reproduces the behaviour he has inherited, supported by the Mummers:

DARNLEY: (As Salome) 'Give me the head of John the Baptist -

With some parsley, on a plate!'

And DARNLEY points right at RICCIO. All three MUMMERS rush at him, pull him to the ground, knives out and as he screams and clutches at MARY's skirt they stab him viciously and drag him off.) (54)

Mary is forced to play Herodes, a just man in Matthew's gospel, whose participation in the plot to kill the prophet is motivated by his wife's influence. The queen's role is passive, as she watches the others proceed, and will only react once Riccio is dead. At this point, she cries for her own death: "Kill me! Go on. Kill me tae. Kill me an' your ain bairn. Go an, ye micht as well. Plunge the knife in. Tear yin ain son oot o' ma tripes an' strangle him wi' yir ain hauns. Because if you dinna he will grow up tae be revenged on ye. Kill me. Kill me. Kill me!" (55). Despite the fact that they are to blame for the tragedy, the Mummers hide behind the title of the scene they control, "The Mask of Salome," so that the characters at their command assume the consequences of their intrigue. On the one hand, they manipulate the scene, since their constant interruptions construct a directed plot: "MUMMER 2: Because a man called John the Baptist-/ MUMMER I: Said: 'Herod! Upon my life (...)"' (53). On the other, they provide their puppets -the other characters- with some degree of fake freedom they control nevertheless. Therefore, once Riccio is murdered and Mary asks to be killed too, Darnley in full rage, moves towards her with this intention in mind, but the Mummers stop him:

MARY: (...) Kill me. Kill me. Kill me! (He is in such a frenzy he might. But MUMMER I grabs his wrist very hard, holds it there. MUMMER 2 draws his sword against DARNLEY's throat.)

MUMMER I: I wouldna dae that, young Henry ...

MUMMER 2: (Tuts.) Regicide, that is.

MUMMER I: Killing a king! Very nasty ... 
MUMMER I: That's no' hoo we dae things here in Scotland.

MUMMER 2: (...) We couldnae hae it, Tam!

MUMMER I: Neither we could, Wullie.

(Pause)

Even though we are at your service, King Henry (Bows).

MUMMER 2: Behind you all the way, king Henry, we're your men, yes, sir. (55)

The hypocrisy in the dialogues reveals the subtlety in the discourses Scottish society is based on. While the Mummers declare their loyalty to the king, they are the agents behind his violent impulses, the ones who direct his rage at Riccio, a foreigner and the character that symbolises the way difference is despised and eradicated from the ideological borders of the nation. Although Mary's depiction is similar, as an ex-centric within the community, but also pregnant and mother of the future king, her symbolic role as "mother of the nation" grants her some time before her death is warranted. ${ }^{3}$ The Mummers save her life this time, but also warn her about the dangers of transgressing their rules:

MUMMER I: There's been a wee bit o' a disturbance an' they're wonderin' if the Queen's a'right.

(They begin to go, DARNLEY flanked by MUMMERS. MUMMER I suddenly wheels back.)

(At MARY) There's nae windaes in here, Ah warn ye, there's twa big strang men staunin' by that door wi' the twa-handit sword and if yi try get oot they will cut ye intae collops! (56)

The interpretation following the Mummers section is twofold. On the one hand, we are invited to reflect on the consequences of reproducing inherited traditions that limit our possibilities, in Jan McDonald y Jennifer Harvie's words, "why representations, including narratives, are controlled the way they are, and who controls them" (1993: 137-138). On the other, the impersonalisation of power through two ambiguous and multiple characters, the Mummers, seems to point at the innocence of those who receive the social structures that determine their lives. As individuals alienated by a system they have not designed, the characters in Lochhead's text repeat the only words they recognise: their cultural heritage. In fact, not even the Mummers escape the harmful consequences of such a system, since they lose their individuality in defence of a hierarchy that will only privilege them as long as they perform the role they have been assigned. At the same time, the only character that will try to escape the oppressive circle that conditions social relations, Marie, the girl Mary Stuart will be transformed into at the end of the play, will be punished for her transgression and killed.

This ambiguity, inscribed in the historical setting of the play, allows for the visualisation of twentieth-century prejudice in the last scene, "Jock Tamson's Bairns," once the characters, "stripped of all dignity and historicity, transformed to twentieth-century children (...) miming childhood games" (63), play the harmful roles they have inherited: bigotry, hate and fear. But the transformation generates ambiguous interpretation again. On the one hand the characters -1980 s Scottish society- seem innocent, as recipients of a tradition

\footnotetext{
${ }^{3}$ It should be remembered that a queen was considered sponsa regni and mater patriae at the time.
} 
they have not created; but on the other, they are also responsible for reproducing the system they inherit, a system they will predictably bequeath to future generations. Significantly enough, Knox is the only adult at the beginning of the scene, and it is he who is in charge of making the viciousness of this tradition evident. A sign of misogynistic and intolerant religious behaviour, he baptises the kids "by pouring a cup of dirty water from his pail over their heads, soaking them" (63). Once his job as transmitter is done, Knox joins this parodic microsociety as another child. At this point, the minister loses his power and adopts a marginal position that will only become central when the rest of the characters need the ideology he preaches to justify Marie's murder: "Wee Knoxxy" is ignored and despised, and will have to concentrate on a ridiculous mantra to keep his faith:

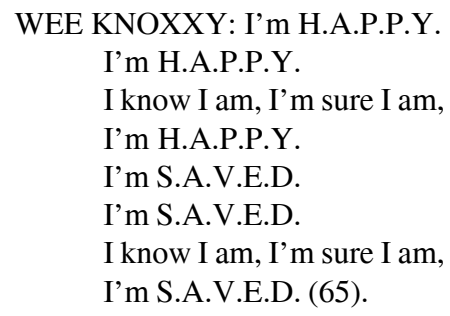

All the characters in this last part of the play are bound by their national identity, except Mary, called Marie this time to underline her difference, a sentiment that corresponds to an essentialist -and simplistic- conception of their cultural roots, parodied in the title of the scene. ${ }^{4}$ Paradoxically, Elizabeth -Wee Bettie-, who should be considered a stranger to the community, according to traditional divisions, organises the pursuit of Marie, an activity the other characters do not hesitate to join, representing the influence of English discourse in the fragmentation of Scottish identity, as well as asymmetrical discursive relations between England and Scotland. Wee Bettie is hence a symbol of the internalisation of English supremacy and Marie's pursuit acts as a metaphor for the atrocities Scottish society has committed against itself, transcending victimising depictions of English oppression. However, there are further implications in the scene having to do with $1980 \mathrm{~s}$ British politics. It was in this decade that Thatcherite politics augmented social differences in Britain and particularly in Scotland, at the same time that ex-centric subjectivites were excluded from the political arena. As a result, marginal identities strengthened their opposition to the norm and found new reasons to express their difference in the field of culture. In this context, it is easy to understand why Lochhead's Wee Bettie and Elizabeth have been identified with the "Thatcher monster" (Varty, 1993: 163), an interpretation that can easily be read in her dialogue with Marie:

WEE BETTY: What's your name anyway?

MARIE: Marie.

\footnotetext{
${ }^{4}$ The Scottish National Dictionary defines "Jock Tamson's Bairns" as "the human race, common humanity, also with less sentimental force, a group of people united by a common sentiment, interest or purpose."
} 
WEE BETTY: Marie? Whit school do you go to?

JAMES HEPBURN: She means urr ye a left-fitter?

Haw, stranger, d'you eat fish oan a Friday?

WEE BETTY: You a Tim?

JAMES HEPBURN: You a Fenian?

WEE BETTY: Are you a Pape?

MARIE: I'm a Catholic. Ih-hih.

WEE BETTY: Ih-hih? How you mean, mmhmm?

MARIE: Just.

(Pause)

WEE BETTY: (Very savage) Well, away and get converted!

Go an' get born again. (64)

James Hepburn, Mary Stuart's third husband and, according to some historical sources, the ultimate cause of her disastrous end, becomes a central character now. Up to this point, the Scottish noble had participated in Marie's chasing along with the others, but his behaviour changes all at once and he becomes her defender. The reasons behind the change do not come from empathy but are motivated by a masculine code that uselessly offers women a kind of protection they do not need. Hepburn seems to represent what Lochhead has defined as the "sentimentalized, violent, self-perpetuating Glasgow and West of Scotland male machismo" that abounds in Scottish culture (Reizbaum, 1992: 182). Despite his offering of protection, Marie despises his help and traditional masculinites at the same time, inducing another change in James Hepburn, who now plays the role of symbolic executioner of those who dare transgress patriarchal authority and the girl is assassinated.

(...) JAMES HEPBURN, who's been no slouch at being part of the torturers, suddenly grabs MARIE, runs away with her.)

JAMES HEPBURN: Leave the lassie alane! (...)

WEE KNOXXY: Haw, Hepburn! Ah think you love her.

WEE BETTY: So do I, I think you love her! You gonny marry her?

JAMES HEPBURN: Nut.

WEE BETTY: Aye, you urr! James Hepburn loves Marie Stewart!

THE REST: James Hepburn loves Marie Stewart!

James Hepburn loves Marie Stewart!

JAMES HEPBURN: I jist says, lea' the lassie alane!

(He pulls what's tied and bundled over her head and MARIE is free, looks right into his eyes. He into hers. She spits right in his face).

Right!

THE REST: Fight! Fight! Fight! Fight! Fight!

JAMES HEPBURN: I am the axeman (66).

It is time now for Wee Betty to show her cruelty and the benefits that Marie's death will offer to the rest: "And eftir you're deid, we'll share oot yir froaks and pu' a' the stones oot yir brooches and gie yir golden slippers a' away to the Salvation Army, and we'll gie' 
the Saint Vincent de Paul" (66). ${ }^{5}$ La Corbie parodies the action in the repetitive song that gives an end -and a beginning - to the story: "Mary Queen of Scots got her head chopped off/ Mary Queen of Scots got her ... head ... chopped ... off" (67). Interpretation is ambiguous again, both related to a negation of social dialogue in Scotland, and to the need for change in its society, to the hope that the repetition of Scottish ideological transmission will sometime in the future create new channels of communication; that the diférance of Scottish cultural signs may allow for the incursion of new ways to interrelate in the nation. As Margery Palmer McCulloch states:

Mary Stuart's motto was 'In my end is my beginning', a motto often reversed as biographers and historical writers portrayed her as a fated figure, predestined by her historical background to come to a sorry end. Lochhead's play could be seen as proposing that by interrogating Mary's life and her ending, by learning from it that we can choose to do otherwise, we contemporary Scots may find our own new beginning (2000: 49).

And indeed Lochhead's text gives some answers -ambiguous as they may be- for Scottish women. If, as Palmer MacCulloch reminds us, Mary Stuart's motto was "in my end is my beginning," and this shall be extended to the experience of any Scot, in a context where gender roles have been so determinant and exclusive as the author has denounced throughout her literary career, we might think of an overall meaning for the play that focuses on the necessary disappearance -a metaphoric "death"- of traditional gender roles in the nation, the kind of roles that Mary Stuart has been a representative of throughout history. After this "death," a phoenix-like resurrection -a redefinition of their foremothers' roles- would be the only way out of the internalised structures that have blocked women's -and ex-centric subjects'- active participation in a Scotland where past prejudice and social inequality still define collective identity.

\section{REFERENCES}

Anderson, B. 1999 [1983]. Imagined Communities. Reflections on the Origin and Spread of Nationalism. London and New York: Verso.

Aston, E. 1994. An Introduction to Feminism and Theatre. London and New York: Routledge.

Bнавна, H., ed. 1994 [1990]. Nation and Narration. London and New York: Routledge. 2000 [1994]. The Location of Culture. London and New York: Routledge.

Crawford, R. 1993. “The Two-Faced Language of Lochhead's Poetry." Liz Lochhead's Voices. Eds. R. CRAWFORD and A. VARTY. Edinburgh UP. 57-74.

HaLl, S. 1993 [1990]. "Cultural Identity and Diaspora.” Colonial Discourse and PostColonial Theory. A Reader Eds. P. WiLliams and L. Christman. New York: Harvester Wheatsheaf. 392-403.

\footnotetext{
5 This section reinforces Palmer McCulloch's connections between Lochhead's text and "The Ballad of the Twa Crows."
}

Odisea, $n^{\circ}$ 5, 2004 
Hutcheon, L. 1989. The Politics of Postmodernism. London and New York: Routledge. LochHEAD, L. 1989. Mary Queen of Scots Got Her Head Chopped Off. London: Penguin.

McDonald, J. and J. Harvie 1993. "Putting New Twists to Old Stories: Feminism and Lochhead's Drama." Liz Lochhead's Voices. Eds. R. CRAWFORD and A. VARTY. Edinburgh UP. 124-147.

MugGlestone, L. 1993. "Lochhead's Language: Styles, Status, Gender and Identity." Liz Lochhead's Voices. Eds. R. CrawFord and A. VARTY. Edinburgh UP. 93-108.

Palmer McCulloch, M. 2000. Liz Lochhead's Mary Queen of Scots Got Her Head Chopped Off. Glasgow: Association for Scottish Literary Studies.

Purkiss, D. 1992. "Women's Rewriting of Myth.” The Feminist Companion to Mythology. Ed. C. LARRInGton. London: Harper-Collins. 441-457.

Reizbaum, M. 1992. "Canonical Double Cross: Scottish and Irish Women's Writing." Decolonizing Tradition: New Views of Twentieth-Century "British" Literary Canons. Urbana and Chicago: University of Illinois Press. 209-217.

Sмiтн, A. D. 1999 [1996]. "Nationalism and the Historians." Mapping the Nation. Ed. G. Balakrishnan. London and New York: Verso/New Left Review. 175-197.

TodD, E. 1995. "Interview with Liz Lochhead." Talking Verse. Ed. R. Crawford. St. Andrews UP. 115-127.

VARTY, A. 1993. "Scripts and Performances." Liz Lochhead's Voices. Eds. R. CRAWFORD and A. VARTY. Edinburgh UP. 148-169.

WiLSOn, R. E. and G. SomERVILLE-ARJAT, eds. 1990. Sleeping with Monsters. Conversations with Scottish and Irish Women Poets. Edinburgh: Polygon. 